\title{
Species composition, abundance and distribution of zooplankton in a tropical eutrophic lake: Lake Catemaco, México
}

\author{
Roberto E.Torres-Orozco B. ${ }^{1}$ and Sandra A. Zanatta ${ }^{1}$ \\ 1 Departamento de Hidrobiología. Universidad Autonoma Metropolitana-Iztapalapa. Apdo. Postal 55-535, C. P. 09340, \\ México, D.F., México, e-mail: rtob@xanum.uam.mx
}

Received 16-VII-1997. Corrected 6-XI-1997. Accepted 20-I-1998.

\begin{abstract}
From April 1992 to May 1993, zooplankton samples were collected monthly by means of horizontal tows in nine sites of the lake. Prior to the towing, temperature of surface water, transparency (Secchi), $\mathrm{pH}$ and dissolved oxygen were evaluated. A total of 31 zooplankton forms, including 14 species of rotifers, three copepods, five cladocerans and one ostracod, as well as protozoans (mainly vorticellids and ciliates), were

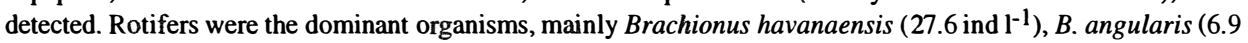
ind $\left.\mathrm{l}^{-1}\right)$, Keratella cochlearis $\left(4.9\right.$ ind $\left.\mathrm{l}^{-1}\right)$, Conochilus unicornis $\left(10.8\right.$ ind $\left.\mathrm{l}^{-1}\right)$ and $C$. dossuarius $\left(3.1\right.$ ind $\left.^{-1}\right)$. Within crustaceans, higher densities were shown by larvae (nauplii and copepodites) of calanoid (16.8 ind $1^{-1}$ )

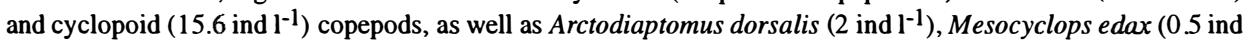

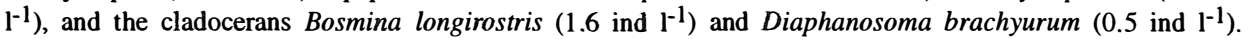
Densities were low, probably because of a high predation pressure imposed by fishes. A gradual increase in total zooplankton density related with a progressive diminution of transparency was observed throughout the sampling period. Zooplankton densities in the stations located at the central part of the lake were higher when compared with those at a more peripheral position. Time variation in rotifer's relative abundance was directly related to temperature fluctuations. The low density and diversity values, the small size of the zooplankters, the presence of an important nurnber of indicator species, and the calanoid copepods: other planktonic crustaceans low ratio, are all indicators of eutrophy. Evidences suggest that the eutrophication process of Lake Catemaco is still progressing rapidly.
\end{abstract}

Key words: Freshwater zooplankton, composition, distribution, abundance, diversity, tropical limnology, Catemaco Lake, México.

Freshwater zooplankton is an important component in aquatic ecosystems whose main function is to act as primary and secondary links in the food chain (Hutchinson 1967, Lind 1985, Wetzel 1975). Despite its relevance, little is known to date about the ecology or even the distribution of tropical limnoplankton (Haberyan et al. 1995). In México, limnological research on plankton is still scant and the available literature is mainly conformed by species check-lists and some taxonomic descriptions. The works of Alcocer et al. (1993) and Sarma et al. (1996) include the majority of the references on the subject. Nowadays, the ecological approach in the study of Mexican limnoplankton is just emerging.

Catemaco Lake is placed in a zone that constitutes the northernmost limit of the tropical rain forest ecosystem in the American continent (Dirzo and Miranda 1992). Little is known about the zooplankton of the lake. The 
works by Suárez et al. (1986) and Tavera (1996) are the only previous studies on the topic and the information offered by them is rather preliminar.

The lake supports an important fishery based on the clupeid fish Dorosoma cf. mexicana, locally known as "topote". Since this is a planktivore fish, the study of the structure and dynamics of the zooplankton community of the lake could render relevant information for the management of this resource, because one of the main problems of Lake Catemaco lies in the risk of exceeding its maximum sustainable yield (Torres-Orozco and Pérez-Rojas 1995).

The aim of this study is to determine the composition, abundance and distribution of the zooplankton community in the surface waters of Lake Catemaco, to establish its space-time variations, and to search for probable relationships between these parameters and some environmental factors.

\section{MATERIALS AND METHODS}

Lake Catemaco is located at the center of Los Tuxtlas region, to the south of the State of Veracruz, México, within $18^{\circ} 21^{\prime}$ y $18^{\circ} 27^{\prime} \mathrm{N}$ and $95^{\circ} 01^{\prime}$ y $95^{\circ} 07^{\prime} \mathrm{W}$, at 332 m.a.s.l. The tropical rainforest that once covered all the watershed of the lake has been severely decimated and has been replaced by cattlefarms and some tropical harvests (TorresOrozco and Pérez-Rojas 1995). Prevailing climate is hot and humid. Annual rainfall averages $1935 \mathrm{~mm}$, with a minimum in March $(25.6 \mathrm{~mm})$ and a maximum in September $(445.9 \mathrm{~mm})$, and a mean temperature of $24.1^{\circ}$ C. January is the coldest month $\left(19.8^{\circ} \mathrm{C}\right)$ and May the hottest $\left(27.2^{\circ} \mathrm{C}\right)$ (Soto 1979). Winds blow strongly over the lake throughout the year. From February to October, northeast winds with an average speed of $3 \mathrm{~m} \mathrm{~s}^{-1}$ are dominant. Colder and faster northern winds blow from November to January. Lake Catemaco has a surface area of 7254 ha, a maximum depth of $22 \mathrm{~m}$ and a mean depth of $7.6 \mathrm{~m}$. According its circulation pattern the lake is polymictic, and it is always well oxygenated (Torres-Orozco et al. 1996).

Water and zooplankton were sampled on a monthly basis, from April 1992 to May 1993 (except in June 1992), at nine stations located in the limnetic zone of the lake (Fig.1). A tow net $(100 \mu \mathrm{m}$ mesh size, $29 \mathrm{~cm}$ diameter in the opening and $99 \mathrm{~cm}$ long) was used for zooplankton collection. A superficial circular towing, lasting $4 \mathrm{~min}$ at a mean speed of $0.83 \mathrm{~m} \mathrm{~s}^{-1}$, was done in each station. All of the samples were taken in the daytime, between 9:00 and 17:00 h. Previously to the zooplankton tow, water temperature at surface, Secchi disk transparency, $\mathrm{pH}(\mathrm{pH}$ meter Corning M103) and dissolved oxygen (Winkler method) were mèasured.

Zooplankton samples were preserved in $4 \%$ neutralized formalin, and stained with Bengal's red before identification and counting. Zooplankton was identified down to genera or species, except for some rare crustaceans. The keys of Edmondson (1959), Koste (1978), Pennak (1978) and Thorp and

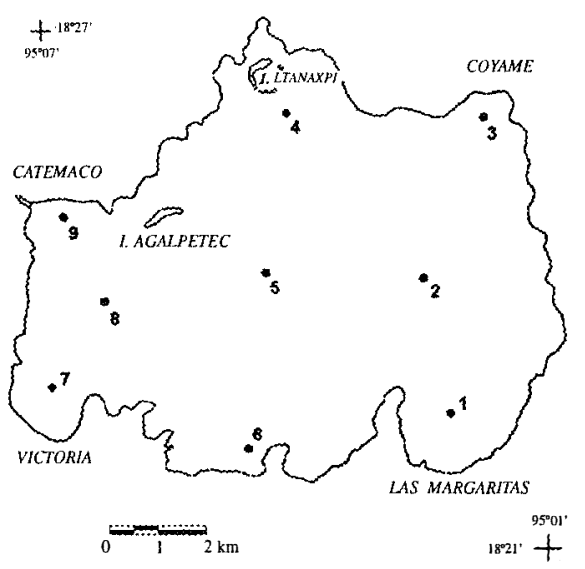

Fig. 1. Lake Catemaco. Collecting sites and toponymy. 
Covich (1991). were used for identification. Nauplii (including copepodites) of calanoid and cyclopoid copepods were counted separately and protozoans where grouped under two main categories: ciliates and vorticellids. Counting was made from subsamples taken with a Hansen-Stempel pipet, and placed in a $1.36 \mathrm{ml}(\mathrm{l}=50, \mathrm{w}=20$, $\mathrm{h}=1.36 \mathrm{~mm}$ ) Sedgwick-Rafter counting cell. Identification and counting were made under an optical microscope (100 x), by the scanning of no less than four randomly chosen longitudinal transects per cell. At least two chambers per sample were analyzed.

As an estimate of the plankton community structure, the Shannon diversitiy index (Shannon and Wiener 1963), eveness and species richness were also evaluated. The observed patterns of distribution, abundance and diversity of zooplankters were related with temperature, transparency $\mathrm{pH}$ and dissolved oxygen variations using non-parametric statistical methods.

\section{RESULTS}

The three most important groups of freshwater zooplankton were counted in the analyzed subsamples. Rotifers, with 14 species, dominated the community, followed by crustaceans, represented by three copepods, five cladocerans and one ostracod, and by protozoans, mainly vorticellids and ciliates (Table 1). Acarii, fish and insect larvae were also recorded in very low densities.

Only eleven of the total zooplankton forms reached annual mean densities higher than 1 ind $1^{-1}$ (Fig. 2). Rotifers were the dominant organisms, mainly Brachionus havanaensis (27.6 ind $\left.\mathrm{l}^{-1}\right), B$. angularis (6.9 ind $\left.\mathrm{l}^{-1}\right), K$. cochlearis (4.9 ind $\left.1^{-1}\right)$, Conochilus unicomis (10.8 ind $\mathrm{l}^{-1}$ ) and $C$. dossuarius (3.1 ind $\left.\mathrm{l}^{-1}\right)$. Within crustaceans, higher densities were shown by larvae (nauplii and copepodites) of calanoid (16.8 ind $\left.\mathrm{l}^{-1}\right)$ and cyclopoid (15.6 ind $\left.1^{-1}\right)$ copepods, as well as Arctodiaptomus dorsalis $\left(2\right.$ ind $\left.\mathrm{l}^{-1}\right)$, Mesocyclops edax (0.5 ind

\section{TABLE 1}

Limnetic zooplankton species of Lake Catemaco (México). Numbers in parentheses are those used in Fig. 7 and refer to the order of domminance of each species in the taxocenoses. n.d.= not determined

Ciliophora

Ciliates

Vorticella spp.

Rotatoria

Brachionus angularis

B. quadridentatus

B. havanaensis

Epiphanes macrurus

Keratella cochlearis

Trichocerca capucina

T. porcellus

T. similis

Asplanchna brightwelli

Polyarthra vulgaris

Filinia longiseta

Hexarthra mira

Conochilus dossuarius

C. unicornis
Ostracoda

Ostracod n.d.

Cladocera

Cladoceran n.d

Cladoceran (juvenil)

Diaphanosoma brachyurum

Bosmina longirostris

Bosminopsis sp.

Moina micrura
Copepoda

Arctodiaptomus dorsalis

Calanoid nauplii

Mesocyclops edax

Cyclopoid nauplii

Cyclopoid n.d.

Other

Acarii

Dipteran larvae (Chaoboridae)

Fish larvae 




Fig. 2. Annual mean densities (ind $\mathrm{l}^{-1}$ ) of the zooplankton species of Lake Catemaco.

$\left.1^{-1}\right)$, and the cladoceran Bosmina longirostris (1.6 ind $\mathrm{1}^{-1}$ ). Our estimate on protozoan populations densities must be lower than its actual value, because of the width of the mesh opening employed.

Spatial and temporal differences in densities of total zooplankton, rotifers, copepods, cladocerans as well as temperature, transparency, $\mathrm{pH}$ and DO were assessed by means of the Kruskal-Wallis non-parametric test. Spatially, none of the variables analyzed showed significant differences. On the contrary, all of these differed on a temporary basis. Given the absence of significant spatial differences, the monthly mean values of these variables were thus used to describe their temporal variations.
Time variation of temperature and Secchi disk transparency are shown in Fig. 3. Transparency exhibited a gradual decline throughout the study period. Surface water temperature fluctuated between $30.5{ }^{\circ} \mathrm{C}$, in May 1992 , and $21.5^{\circ} \mathrm{C}$, in January 1993 . In general, a hot period from April to September can be distinguished from a relatively cold one, from October to March. Monthly mean values of $\mathrm{pH}$ were rather alcaline. These averaged 8.99 throughout the year and varied from 8.25, in April 1992, to 9.52, in October 1992. Dissolved oxygen (DO) concentrations were always high and showed minor variations. Extreme DO values were detected in August and October 1992, with 10.2 and 6.0 mg $1^{1-1}$, respectively. 



Fig. 3. Seasonal variations of transparency (a) and temperature (b) throughout the study period.

A gradual increase in total zooplankton density was observed along the sampling period (Fig. 4). Regarding spatial variations, although the analysis of the complete data did not yield significant differences, mean densities of total zooplankton in the stations placed at the central part of the lake appear to be higher than those placed in a more peripheral position (Fig. 5). Therefore, the Wilcox's non-parametric comparison for two paired samples was applied to the densities of the stations, clustering them within three groups: northern (stations 3, 4 and 9), central $(2,5,8)$ and southern $(1,6,7)$. This test showed no important differences in density between the northern and southern groups $(z=0.72$, probability of equality, $p=47.24 \%$ ), but the central group differed from the northern $(\mathrm{z}=2.44, \mathrm{p}=1.48 \%)$ and the southern one $(\mathrm{z}=$ $1.9245, \mathrm{p}=5.42 \%)$. Station 7, located off the town of Victoria, showed the lowest density.



Fig. 4. Temporal variation in zooplankton total density.

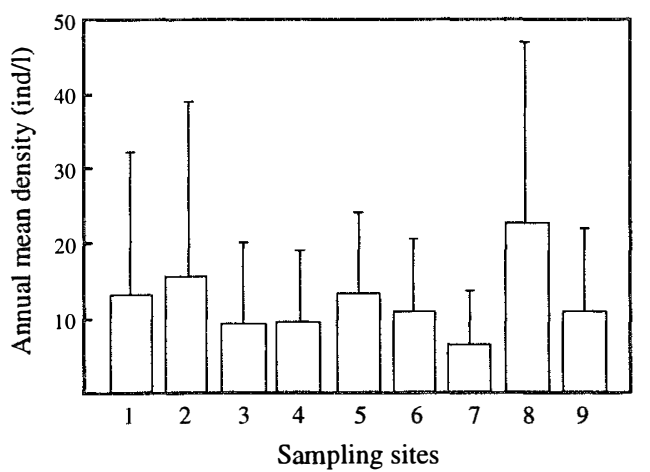

Fig. 5. Differences in zooplankton mean densities by sampling stations.

Monthly variations in the relative abundance of the main zooplankton groups showed that rotifers dominated community composition during most of the year, with abundances over $60 \%$ (Fig. 6). Nevertheless, rotifers declined in September 1992, when they were replaced by cladocerans that reached a relative density higher than $75 \%$. In the coldest part of the year (December 1992 to March 1993) copepods, represented mainly by its larval stages, dominated numerically.

When densities of the main zooplankton groups and environmental parameters were correlated (Spearman rank non-parametric correlations) only some of the resulting values 


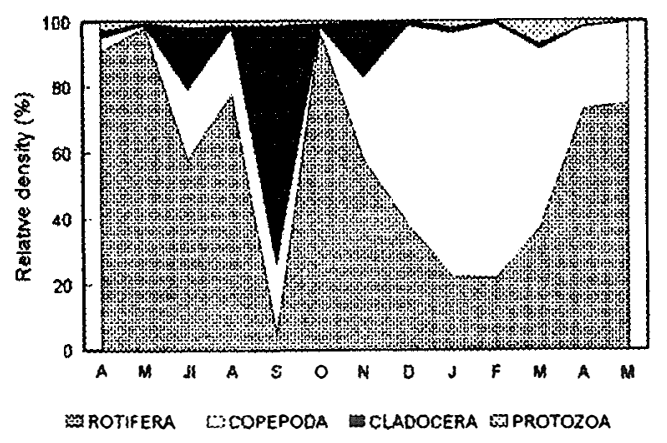

Fig. 6. Seasonal variation of the relative proportions of the main zooplankton groups in Lake Catemaco (1992 -1993).

were high enough and of statistical significance. Total zooplankton density was inversely related to Secchi disk transparency $\left(r_{s}=-0.50, p=\right.$ 0.0000 ; but this correlation was higher when using monthly mean values: $r_{s}=-0.66, p<0.03$ ). Rotifer relative density correlated well and positively with temperature $\left(\mathrm{r}_{\mathrm{s}}=0.62 \mathrm{p}=\right.$ 0.0000 ). For the crustaceans, correlation with temperature was inverse $\left(\mathrm{r}_{\mathrm{s}}=-0.54, \mathrm{p}=0.0000\right.$ for copepods and $r_{s}=-0.29, p>0.004$ for cladocerans). A positive correlation of $\mathrm{pH}$ with Rotifer relative density $\left(r_{s}=0.34 p=0.0007\right)$ and a negative one with Cladocerans $\left(r_{s}=-0.29\right.$, $p>0.003$ ) were also observed. No significant correlations were obtained between any taxa and DO concentrations.

To establish if any single species or taxon controls the global variations already described, the Olmstead and Tukey (Sokal and Rholf 1979) association test was used. This test correlates the mean abundance of each species with its frequency of occurrence, and makes it possible to recognize at least four different strategies of habitat usage (Fig. 7). The resulting most frecuent and abundant species (superior right quadrant) were chosen to illustrate temporal variation patterns. These were the rotifers Conochilus unicornis, $C$. dossuarius, Brachionus havanaensis, $B$. angularis and Keratella cochlearis; the

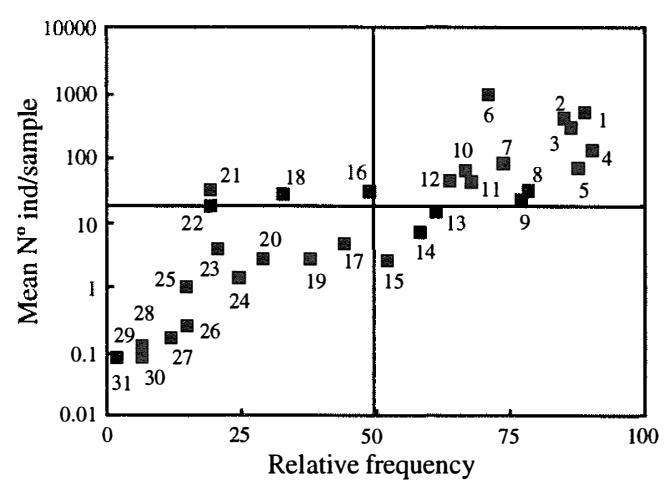

Fig. 7. Olmstead and Tukey association test for the zooplankton species of Lake Catemaco. Numbers correspond to the species listed in Table 1.

copepods Arctodiaptomus dorsalis y Mesocyclops edax, as well as the nauplii and copepodites of calanoid and cyclopoid copepoda, and the cladocerans Bosmina longirostris and Diaphanosoma brachyurum.

When monthly variations of the densities of dominant species were plotted (Fig. 8), a sort of succession was observed between some rotifer populations. Conochilus unicomis, for example, showed high densities through the first months of the study period but afterwards it declines, giving place to the rise of $C$. dossuarius, B. havanaensis, B. angularis and $K$. cochlearis populations. As to crustaceans, copepods reached their higher densities during the cold part of the year (from December 1992 to March 1993), though in May 1993 almost all zooplankton densities were also high. Within cladocerans, Diaphanosoma brachyurum was always found in low densities, except in July 1992 when its density peaked over 4 ind $1^{-1}$. Cladoceran Bosmina longirostris, nearly absent in the first four months, increased its abundance during the coldest months.

Indices of diversity, eveness and species richness were employed as parameters to define the structure of the zooplankton community in the lake. In this analyses, nauplii (copepodites included) of calanoid and cyclopoid copepods 

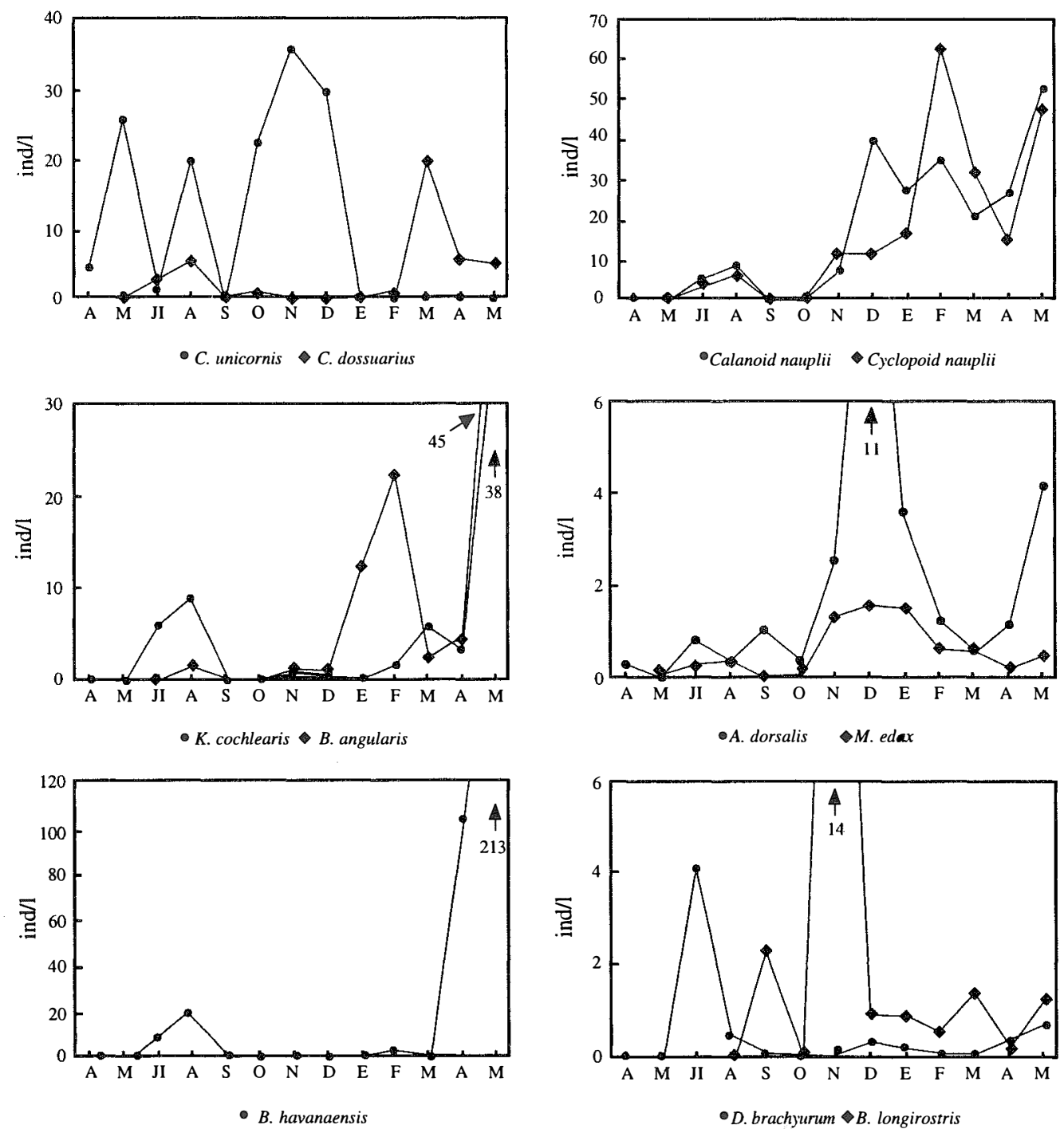

Fig. 8. Temporal shifts in the total abundance of the zooplankton dominant species.

were taken as species because they are too abundant to ignore them and, if not from a taxonomic point of view, they do, in a functional sense, add information to the community (Carrillo et al. 1987). None of these parameters showed significant differences (Kruskal-Wallis test) in space, but all of them varied significantly in time. The mean values of this indices were rather low (Fig. 9). In may 1992, low diversity and eveness point to the dominance of some taxa. The lowest values for this indices were observed in station 5, located at the center of the lake $\left(12.5\right.$ species, $H^{\prime}=1.13$, $\left.\mathrm{J}^{\prime}=0.43\right)$, whereas station 9, adjacent to Catemaco City, showed the highest values (15.9 species, $\left.\mathrm{H}^{\prime}=1.71, \mathrm{H}^{\prime}=0.63\right)$. Nevertheless, spatial differences in this parameters lacked statistical significance even when data were grouped in the same way as described before, when comparing densities in-between zones. 


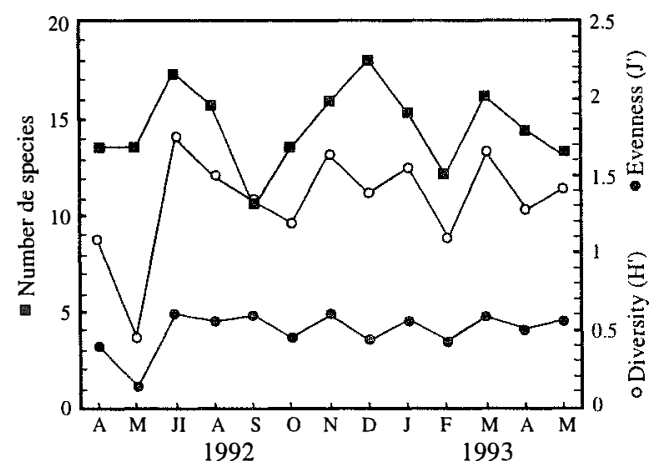

Fig. 9. Seasonal variations in species richness, diversity $\left(\mathrm{H}^{\prime}\right)$ and eveness ( $\left.\mathrm{J}^{\prime}\right)$.

\section{DISCUSSION}

Rotifers, with a relative abundance of $57.7 \%$, were identified as the dominant taxa within the zooplankton community of the lake, followed by copepods (31.6\%), cladocerans $(9.04 \%)$ and protozoans $(1.5 \%)$. Our results differ from those reported by Suárez et al. (1986) who, on the basis of samples collected quarterly between 1981 and 1982, found copepods to be the dominant taxa (40\%), followed by cladocerans, (21.4\%), nauplii of copepods $(19.73 \%)$ and rotifers $(7.9 \%)$. Since they only found four species of rotifers (Brachionus havanaensis, Asplanchna priodonta, Keratella americana and Filinia sp.), four of copepods (Diaptomus albuquerquensis, Eucyclops agilis, Macrocyclops albidus and Halicyclops sp.) and one clacoceran (Bosmina longirostris), the majority of the species cited herein constitute new records for the lake. Within crustaceans, Suárez et al. (1986) only found a calanoid species which was identified as Diaptomus albuquerquensis; nevertheless, the presence of dorsal keels in the fifth somite of the specimens collected in this study lead us to state that the only calanoid copepod inhabiting Lake Catemaco is actually Arctodiaptomus dorsalis.

The scarcity of rotifers in the samples of Suárez et al. suggests they used a mesh diameter wider than $100 \mu \mathrm{m}$ (the type of net used is not stated in their paper); this could lead to the underestimation of the relative abundance of rotifers, whereas larger zooplankters, like copepods and cladocerans, would be overestimated. The absence in our samples of some of the species recorded by them would imply that our collecting was done far from shallow nearshore sites, usually richer in zooplankton species. Other differences could also be attributed to the huge difference in size of the samples counted (1342 zooplankters counted by Suárez et al., versus 291541 counted by us). Observed differences in zooplankton composition could thus involve differences in the methods used for collection and treatment of the samples. However, the posibility of actual changes in the zooplankton community in the years elapsed between both studies cannot be discarded. In Costa Rican lakes, Haberyan et al. (1995) found that the zooplankton community composition can change completely in a matter of a few years. Thus, the probable existence of important interannual shifts in the planktonic fauna of Lake Catemaco points to the need for more studies on an anual basis, as well as on longer terms.

According to our results, the zooplankton community of Lake Catemaco is typical of an eutrophic environment. Many species cited by Gannon and Stemberger (1978) as indicators of eutrophy abounded in our samples, at least occasionally. Examples of them were rotifers Brachionus angularis, $B$. quadridentatus, Keratella cochlearis, Filinia longiseta, Polyarthra vulgaris, Trichocerca capucina and Conochilus dossuarius, and the cladoceran Bosmina longirostris. Furthermore, the calanoid copepods: total planktonic crustaceans low ratio, proposed by them as a useful indicator of the trophic state, points to the same conclusion, since only one calanoid species was detected within planktonic crustaceans.

Densities were low for most zooplankton populations. Nilssen (1984) has addressed that zooplankton communities could be very simplified in the tropics, and very low 
densities are not infrequent in tropical lakes. In Lake Victoria, for instance, Gophen et al. (1993) found only five species of copepods with densities from 3 to 106 ind $\mathrm{l}^{-1}$, six species of cladocerans and 10 species of rotifers, with 0 to 50 ind $1^{-1}$. In turn, in Lake Naivasha (Kenya), a lake characterized by the absence of vertebrate zooplanktivores and the virtual absence of invertebrate predators, Mavuti and Litterick (1981) found three species of copepods, 11 cladocerans and 12 rotifers, and a total zooplankton density that fluctuated between 250 to 60 ind 1-1 troughout the year. The low density of the zooplankton in Lake Catemaco cannot be considered a symptom of food limitation because phytoplankton is very rich and, though not all phytoplankton species are edible, there is enough biomass to support much more zooplankton than that which is actually found (Tavera 1996). The explanation for these low densities must thus lie in ecological relationships, like competition and predation. Nevertheless, since all the collections were made during daytime in surface waters, the low densities observed could also involve the occurrence of migratory behavior in the zooplankters. Thus, at the time of the sampling, zooplankters coud be concentrated in the deeper layers of the lake, searching for shelter; this could led to underestimate densities, as well as the species richness and composition. Although diel vertical migration has not been studied in Lake Catemaco, such behavior has been observed in a neighboring lake, Laguna Escondida, $17 \mathrm{~km}$ northward from Catemaco (Torres-Orozco and Estrada 1997).

A sort of succesion observed in the populations during the study (Fig. 8) suggests competition, and there are some clues that could be interpreted as evidences of high predation pressure. One of these is the small size of zooplankters. Within the crustaceans we didn't found daphnids nor other large cladocerans, and taxocenoses appeared dominated by two small copepod species and their nauplii and copepodite stages. Since predator avoidance in zooplankton is often attained through the reduction of body size (Hutchinson,1967), this fact alone suggests that predation pressure is high. Furthermore, it is well established that large zooplankters are eaten by a higher number of predator species (Zaret 1980, Dodson 1988), and that increased planktivore pressures can lead to the extermination of large species and their subsequent replacement by smaller ones (Brooks 1968, Gannon and Stemberger 1978, Zaret and Suffern 1976).

The most abundant fishes of Lake Catemaco are the shad Dorosoma cf. mexicana, (locally named topote), the caracin Bramocharax caballeroi and the poecilids: Xiphophorus milleri, Xiphophorus n. sp., Poecilia catemaconis, Poeciliopsis catemaco, and Heterandria n. sp., as well as two native cichlid species of Cichlasoma and the exotic Tilapia aurea (Miller and Van Conner 1997). Almost all of them are planktivorous in some stage of their life cycles. Adults of Dorosoma cf. mexicana fed almost exclusively on phytoplankton (Tavera 1996) but, although the food preferences of the juveniles of this shad have not been studied so far in Lake Catemaco, it is known that species of Dorosoma feed on zooplankton at early stages (Barger and Kilambi 1980, Dettmers and Stein 1992). Poecilids are mainly omnivores, and feed on a mixture of terrestrial and aquatic invertebrates, detritus, algae, and vascular plants (Meffe and Snelson 1989); given their opportunistic character, they also can be considered as important zooplankton predators.

The yields of the topote fishery in Lake Catemaco reached a mean of 673 ton $\mathrm{yr}^{-1}$ in the 80's (Torres-Orozco and Pérez-Rojas 1995); this could give some idea of the magnitude of predation pressure imposed by its larvae and juveniles on zooplankton. We must add to the above pressure the one excerted by poecilids and other fish species that, at least at its early stages, predate on zooplankton. 
The abundance of the zooplankton community showed a temporal pattern of variation that correlates inversely with Secchi disk transparency (Fig. 3). Thus, since transparency is a good indicator of phytoplankton and organic matter abundance in a lake (José de Paggi 1993), this relationship is seen as a response of zooplanktic populations to an increase in food availability. The shift of the physical and chemical features of the lake towards eutrophy can also be related with the observed changes in zooplankton community composition. In lakes where planctivores abound, though, it can be difficult to distinguish which of these changes come as a result of predation, eutrophication or both (Gannon and Stemberger 1978). The answer to this question requires further studies.

The monthly fluctuations in rotifer relative abundance were directly related with water temperature variations (compare figs. 6 and 3). It has been demonstated that abundance of rotifers closely follows temperature variations, because temperature has a major influence on their reproductive rate, feeding, movement and longevity (Ruttner-Kolisko 1974, Wetzel 1975). From December to March, low water temperatures led to a decrease of rotifer populations and their replacement by copepods, represented mainly by their larvae.

Regarding spatial variations, zooplankton densities in stations located at the center of the lake were high when compared to those placed in a more peripheral position. Spatial differences in density seem to be related with prevailing winds and the pattern of water currents imposed by them. Prevailing winds from the Gulf of México enter the Catemaco watershed through an opening in the sorrounding sierra located to the north of the town of Coyame, and cross the lake in a NE-SW direction. The wind's direction, influenced by the shape of the lake, produces water currents that spin clockwise, trailing sestonic particles off the shores and accumulating them in the central area (as in the vortex of a swirl). Station 7 showed the lowest abundances throughout the study period. This could be related with the high hydrodynamics of the zone, where a constant wind produces high turbulence and heavy waves nearshore. These conditions disfavour the development of zooplankton populations.

Mean values of the diversity and eveness indexes as well as species richness calculated for this study were rather low and typical of eutrophic waters (Carrillo et al. 1987). Also, the small body size of zooplanktic species, the presence of an important number of indicator species, the calanoid copepods: other planktonic crustaceans low ratio, and the low densities observed, are all indicators of eutrophy. Furthermore, it is very probable that the eutrophication process of Lake Catemaco is progressing rapidly; such a tendency was observed even in the brief lapse of the months considered in this study. Evidences of this are the progressive decrease of transparency and the substitution of Conochilus unicornis by $C$. dossuarius, an indicator species of eutrophy.

\section{ACKNOWLEDGMENTS}

This study was supported with funds provided by the División de Ciencias Biológicas y de la Salud of the Universidad Autónoma Metropolitana - Iztapalapa. We thank the help in the field work of our colleagues and students, specially to Alberto Pérez-Rojas, Elizabeth Camps, Mónica Estrada and Emilio Revueltas. S.S.S. Sarma assisted us in the identification of the rotifer species and Marco A. PérezHernández in the statistical analyses. José Luis García-Calderón and Anselmo Galindo Molina made valuable comments on the manuscript.

\section{RESUMEN}

Entre abril de 1992 y mayo de 1993, se realizaron mensualmente recolectas subsuperficiales de zooplancton, con red, en nueve localidades del lago, en donde también 
se determinaron la temperatura superficial, la visibilidad del disco de Secchi, el pH y la concentración de oxígeno disuelto. Entre las 31 formas de plancton detectadas en las distintas submuestras se registraron 14 especies de rotíferos, tres de copépodos, cinco de cladóceros y un ostrácodo, además de protozoarios, principalmente vorticélidos y ciliados. Los rotíferos fueron los organismos más abundantes; Brachionus havanaensis fue la especie dominante, seguida por Conochilus unicornis, Brachionus angularis, Keratella cochlearis y Conochilus dossuarius. Entre los copépodos destacaron Arctodiaptomus dorsalis y Mesocyclops edax, además de sus nauplios y copepoditos, y entre los cladóceros Diaphanosoma brachyurum, Bosmina longirostris, y Bosminopsis sp. Las densidades observadas en los grupos dominantes del zooplancton fueron bajas; sin embargo, a lo largo del período de estudio se observó un incremento paulatino en la densidad zooplantónica total, relacionado con una disminución progresiva de la visibilidad del disco de Secchi. Las densidades más altas se detectaron en los sitios más alejados de la costa. Las variaciones estacionales en la abundancia relativa de los rotíferos estuvieron estrechamente relacionadas con las fluctuaciones de la temperatura. Los bajos valores de densidad y diversidad, el pequeño tamaño de los zooplancters, la presencia de un importante número de especies indicadoras y la baja razón copepodos calanoides: otros crustáceos planctónicos, son todos indicadores de condiciones eutróficas. Además, existen evidencias de que el proceso de eutrofización del lago está avanzando aceleradamente.

\section{REFERENCES}

Alcocer, J., M. Chávez \& E. Escobar. 1993. La limnología en México (Historia y perspectiva futura de las investigaciones limnológicas). Ciencia 44: 441-453.

Barger, L. E. \& R. V. Kilambi. 1980. Feeding ecology of larval shad, Dorosoma, in Beaver Reservoir, Arkansas. U. S. Fish and Wildlife Service, Biological Services Program FWS/OBS80/43: 136-145.

Brooks, J. L. 1968. The effects of prey size selection by lake planktivores. Syst. Zool. 17: 272-291.

Carrillo, P., L. Cruz-Pizarro, R. Morales \& P. SánchezCastillo. 1987. Cambios estacionales en las comunidades de fitoplancton y de zooplankton de la Albufera de Adra. Limnética 3: 243-254.

Dettmers, J. M. \& R. A. Stein. 1992. Food consumption by larval gizzard shad: zooplankton effects and implications for reservoir communities. Trans. Amer: Fish. Soc. 121: 494-507.

Dirzo, R. \& A. Miranda. 1992. El límite boreal de la selva tropical húmeda en el continente Americano: contracción de la vegetación y solución de una controversia. Interciencia 16: 240-247.

Dodson, S. 1988. The ecological roll of chemical stimuli for the zooplankton: predator-avoidance behaviour in Daphnia. Limnol. Oceanogr. 33: 1431-1439.

Edmondson, W. T. 1959. Fresh water biology. Wiley, New York. $1248 \mathrm{p}$.

Gannon, J. E. \& R. S. Stemberger. 1978. Zooplankton (especially crustaceans and rotifers) as indicators of water quality. Trans. Amer. Microscop. Soc. 97: 16-35.

Gophen, M., P. B. O. Ochumba, U. Pollingher \& L. S. Kaufman. 1993. Nile perch (Lates niloticus) invasion in Lake Victoria (East Africa). Ver. Internat. Ver. A. Limnol. 25: 856-859.

Haberyan, K. A., G. Umaña V., C. Collado \& S. P. Horn. 1995. Observations on the plankton of some Costa Rican lakes. Hydrobiologia 312: 75-85.

Hutchinson, G. E. 1967. A treatise on limnology, Volume II. Introduction to lake biology and the limnoplankton. Wiley, New York. 1115 p.

José de Paggi, S. 1993. Composition and seasonality of planctonic rotifers in limnetic and littoral regions of a floodplain lake (Parana river system). Rev. Hydrobiol. trop. 26: 53-63.

Koste, W. 1978. Rotatoria. Die Rädertiere Mitteleuropas. Ein Bestimmungswerk berg. von Max Voigt. Überordnung Monogononta. Vol. 1-2. 673 p. + 234 pl.

Lind, O.T. 1985. Handbook of common methods in limnology. Kendall/Hunt, Dubuque, Iowa. 199 p.

Mavuti, K. M. \& M. R. Litterick. 1981. Species composition and distribution of zooplankton in a ropical lake, Lake Naivasha, Kenya. Arch. Hydrobiol. 93: 52-58.

Meffe, G. K. \& F. F. Snelson Jr. 1989. An ecologycal overview of poeciliid fishes. p. 13-31. In G. K. Meffe \& F. F. Snelson Jr. (eds), Ecology and evolution of livebearing fishes (Poeciliidae). Prentice Hall. Englewood Cliffs, New Jersey.

Miller, R. R. \& J. Van Conner. 1997. Peces de Catemaco. p. 451-456. In E. González-Soriano, R. Dirzo \& R. C. Vogt (eds), Historia Natural de Los Tuxtlas. Universidad Nacional Autónoma de México, México, D.F.

Nilssen, J. P. 1984. Tropical lakes -functional ecology and future development: the need for a process-oriented approach. Hydrobiologia 113: 231-242. 
Pennak, R. W. 1978. Fresh-water invertebrates of the United States. Wiley, New York. 803 p.

Ruttner-Kolisko, A. 1974. Planktonic rotifers, biology and taxonomy. Binnengewässer (Supplement) 26: 1-146.

Sarma, S. S. S., M. Elías-Gutiérrez \& C. Serranía. 1996. Rotifers of high altitude crater-lakes at Nevado de Toluca Volcano, México. Hidrobiológica 6: 33-38.

Shannon, C. E. \& W. Wiener. 1963. The mathematical theory of communication. University of Illinois, Urbana.

Sokal, R. S., \& F. S. Rholf. 1979. Biometría. Blume, Barcelona. $832 \mathrm{p}$.

Soto, M. 1979. Algunos aspectos climáticos de la región de Los Tuxtlas, Ver. p. 70-111. In A. Gómez-Pompa, S. del Amo \& A. Butanda (eds), Investigaciones sobre la regeneración de selvas altas en Veracruz, México. CECSA, México, D. F.

Suárez M., E., L. Segura \& M. A. Fernández. 1986. Diversidad y abundancia del plancton en la Laguna de Catemaco, Veracruz durante un ciclo anual. An. Inst. Cienc. del Mar y Limnol. Univ. Nal. Autón. México 13: $313-316$

Tavera, R. L. 1996. Phytoplankton of the tropical Lake Catemaco. Ph. D. Thesis. Univ. of South Bohemia.
Facu lty of Biological Sciences. Cंzech Republic. 63pp. +15 figs. \& 14 tabs.

Thorp, H. J. \& A. P. Covich. 1991. Ecology and classification of North American freshwater invertebrates. Academic Press, San Diego. 911 p.

Torres-Orozco B., R., C. Jiménez-Sierra \& A. Pérez-Rojas. 1996. Some limnological features of three lakes from Mexican neotropics. Hydrobiologia 431: 91-99.

Torres-Orozco B., R. \& M. Estrada Hernández. 1997. Patrones de migración vertical en el plancton de un lago tropical. Hidrobiológica 7: 33-40.

Torres-Orozco B., R. \& A. Pérez-Rojas. 1995. El Lago de Catemaco. p. 155-175. In G. de la Lanza \& J. L. García Calderón (eds), Lagos y Presas de México. Centro de Ecología y Desarrollo, México, D.F.

Wetzel, G. R. 1975. Limnology. W. B. Saunders, Filadelfia, Pensilvania. 743 p.

Zaret, T. M. 1980. Predation and freshwater communities. Yale University, New Haven, Connecticut. 187 p.

Zaret, T. M. \& J. S. Suffern. 1976. Vertical migration in zooplankton as a predator avoidance mechanism. Limnol.Oceanogr. 21: 804-813. 